\title{
Mülteci Çocukların Resimlerinde Oyun Algısı
}

\author{
Raziye PEKŞEN AKÇA ${ }^{1}$ ve Fatih AYDOĞDU ${ }^{2}$ \\ $\ddot{O} z$
}

$\mathrm{Bu}$ araştırmada mülteci çocukların oyuna ilişkin algılarının resim yoluyla incelenmesi amaçlanmıştır. Araştırmada çalışma grubu ölçüt örneklemeye göre belirlenmiştir. Bu bağlamda araştırmada "Suriye' den savaş nedeniyle gelmiş olma", "Hatay ilinde ikamet etme" ve "çalışmaya katılmaya gönüllü olma" ölçütleri dikkate alınarak çalışma grubu oluşturulmuştur. Bu amaçla araştırmaya Hatay ilinin Reyhanlı ilçesinde 2019-2020 eğitim öğretim yılında, ilkokul birinci sınıfa devam eden ve son bir yıl içerisinde Hatay iline savaş nedeniyle göç etmiş olan 32 ( $E=16 ; K=16)$ mülteci çocuk dâhil edilmiştir. Çocukların ailelerinin ve kendilerinin demografik bilgilerine kişisel dosyalarından ulaşılmıştır. Araştırmada çocuklara "Severek oynadığın bir oyunun resmini çizer misin?” yönergesi verilerek resim çizdirilmiştir. Çocuklara süre konusunda sınırlandırılma yapılmamış, çocuklardan resimlerini anlatmaları istenmiş, çalışmasını tamamlayan çocukların resimlerine ilişkin ifadeleri ayrı ayrı not edilmiştir. $\mathrm{Bu}$ süreçte bağımsız bir tercümandan ve bir rehberlik ve psikolojik danışmanından destek alınmıştır. Elde edilen veriler nitel veri analizine uygun QSR NVivo 10 bilgisayar programıyla çözümlenmiştir. Çözümlemelerde betimsel analiz tekniği kullanılmıştır. Sonuç olarak çocukların hemen hemen bütün renkleri kullandıkları, savaşın izlerini taşıyan kısımları daha belirgin çizdikleri ve mutlu oldukları görülmektedir.

Anahtar Kelimeler: Mülteci Çocuk, Oyun, Resim, Nitel Araştırma

\section{Game Perception in the Pictures of Refugee Children}

\section{Abstract}

In this study, it was aimed to examine the perceptions of refugee children about play through drawing. Study group was determined according to criterion sampling method. In this context, the study group was formed by taking into account the criteria of "coming from Syria due to war", "residing in the province of Hatay" and "volunteering to participate in the study". For this purpose, $32(\mathrm{M}=16 ; \mathrm{F}=16)$ refugee children attending the first grade of primary school in Reyhanl district of Hatay province in 2019-2020 academic year and migrated to Hatay province due to war in the last year were included in the study. Demographic information of the children's families and themselves was obtained from their personal files. Sample of this study consisted of children attending to first grade at Hatay Temporary Education Facility in spring term of 2019-2020 academic years. In the study, the children were drawn by giving the instruction "Would you draw a picture of a game you love to play?". The children were not limited in terms of time, they were asked to explain their pictures, and their statements about the pictures of children who completed their work were noted separately. In this process, support was received from an independent translator and a guidance and psychological counselor. Quantitative data obtained was analyzed by using QSR NVIVO 10 software. Analysis involved descriptive analysis technique. As a result, it is seen that children use almost all colors, draw the parts that bear the traces of the war more clearly and they are happy. Keywords: Refugee Child, Play, Painting, Qualitative Research

Key Words: Refugee Children, Game, Draw, Qualitative Research

\section{Atıf İçin / Please Cite As:}

Pekşen Akça, R. ve Aydoğdu, F. (2021). Mülteci çocukların resimlerinde oyun algısı. Manas Sosyal Araştırmalar Dergisi, 10(1), 58-69.

Geliş Tarihi / Received Date: 05.05.2020

Kabul Tarihi / Accepted Date: 02.10.2020

\footnotetext{
1 Öğr. Gör. Dr. - Kayseri Üniversitesi Develi Hüseyin Şahin Meslek Yüksekokulu, rpeksenakca@gmail.com

(D) ORCID: 0000-0003-1989-8212

2 Dr. Öğr. Üyesi - Erzincan Binali Yıldırım Üniversitesi Sağlık Hizmetleri Meslek Yüksekokulu, mailadresi@gmail.com 


\section{Giriş}

Birçok eşitsizliğe karşı savunmasız, dezavantajlı bir grup olan mülteciler eğitim, sağlık, istihdam, yabancı dil, ekonomik ve sosyal hayatla ilgili pek çok sorunla karşı karşıyadır (Saleh, Aydın ve Koçak, 2018). Bu sorunlardan yalnızca yetişkin mülteciler değil, çocuklar da etkilenmekte, göç süreci çocuklar üzerinde pek çok olumsuz durumun oluşmasına sebep olmaktadır (Wang, Zhou ve Hesketh, 2017). Bu süreç bir çocuk için göçün kiminle gerçekleştirildiğine bakılmaksızın (aile üyeleri, tanıdık ya da tek başına) onun mülteci olarak anılmasına neden olmaktadır. Bu çocuklar çocukluğun olağan gelişimsel deneyimlerini yaşadıkları gibi aynı zamanda sıra dışı mültecilik deneyimlerini de yaşamak zorunda kalan çocuklardır (Derluyn ve Vervliet, 2012). Zira göç öncesi, göç sırası ve göç sonrasında yaşanılanlar çocukları ruhsal ve gelişimsel açıdan etkilemektedir (Aydoğdu, 2019).

Mülteci çocuklar göç öncesinde savaşın da bir sonucu olarak şiddete, işkenceye, aile yakınları ya da arkadaşlarının kaybına tanıklık edebilmektedir. Mülteci çocuklar kimi zaman göç sırasında insan kaçakçıllğ̆ ya da farklı tehditlerle de karşı karşıya kalabilir. Göç sonrasında da mülteci çocuklar yeni bir okula uyum güçlüğü, arkadaş edinememe ve erken dönemde yetişkin rollerini üstlenme gibi pek çok olumsuzluklar yaşayabilir (Düzel ve Alış, 2018; Fazel ve Stein, 2000). Çocukların deneyimledikleri bu travmatik yaşantılar ileriki yaşamlarında da silinmeyecek izler bırakabilir (Lawrence, Dodds, Kaplan ve Tucci, 2019). Hatta çocukların yaşadığı travmatik olaylar onların aile içinde çatışmalar yaşamalarına ve göç ettikleri toplumdaki bireylerle sağlıksız ilişkiler kurmalarına da neden olabilir. Bununla birlikte göç eden çocukların eğitim seviyesinin düşük olması, ekonomik sorunlar, sosyal güvenliğin olmaması ve kültürel farkl11ıklar çocukların toplumsallaşma çabalarını olumsuz yönde etkileyebilir (Aydoğdu, 2019). Göç eden çocuklar akranlarıyla karşılaştıııldıklarında sağlıksız ortamlarda yaşama, temel ihtiyaçların karşılanmasında daha çok güçlük çekme, çalışma hayatına erken yaşlardan itibaren sürüklenme (Baş, Molu, Tuna ve Baş, 2017), okula gitme oranlarının akranlarına göre daha düşük olma (Hing, Lun ve Phann, 2014), eğitimlerine yönelik uygulamalarda ebeveyn desteği almakta yetersiz kalma (Hanson ve Woodruff, 2003; Pottinger ve Brown, 2006), şiddet ve istismar gibi olumsuz durumlarla karşı karşıya olma (Rossi, 2008), daha fazla psikolojik sorunlar yaşama gibi durumlarla karşı karşıya oldukları belirtilmektedir (Vanore, 2015).

Savaş nedeniyle ülkesini terk etmek zorunda kalan Suriyeli mülteciler, başta Türkiye olmak üzere pek çok dünya ülkesinde sığınmacı olarak yeni bir yurt arama çabası içerisindedirler. Suriyeli mülteciler savaşın bir sonucu olarak; öldürme, zulüm, ev hasarı, sağllk ve eğitim hizmetlerinden yoksun kalma korkusu nedeniyle ülkelerini terk etmek zorunda kalmıslardır (Attanayake vd., 2009). Mültecilerin güvenli bir ortama göç etmelerinde pek çok etmen belirleyicidir. Bu etmenler arasında güvenli bir yere göç etme (Özdemir ve Budak, 2017), göç sırasında daha az güçlük çekme, bölgesel yakınlık ve kültürel benzerlik yer alabilir. Ancak buna rağmen savaş nedeniyle göç etmek zorunda kalan mülteciler bu süreci kendileri lehine çıkarmak için göç edecekleri ülkede pek çok olumlu yön belirlemelerine rağmen çocuklar bu süreçten derin etkilenmektedir. Nitekim Sirin ve Rogers Sirin (2015)'in yapmış olduğu çalışmada, mülteci çocukların \% 45 ' inde travmaya bağlı stres bozukluğu, \% 44'ünün de depresyon belirtileri gösterdikleri görülmüştür. Bu doğrultuda göçün çocuklar üzerinde ruhsal ve psikolojik bazı sorunlar ortaya koyduğu belirtilebilir.

Türkiye'de mülteci çocukların yaşadıkları sorunların belirlenmesine yönelik bazı çalışmalar yapılmıştır. Bu çalışmalarda her üç Suriyeli çocuktan birinin çalıştığı veya iş aradığı (Bahadır ve Uçku, 2016), çocuklar için hazırlanan eğitim programının onların sosyal duygusal gelişimlerine olumlu etkisi olduğu (Kardeş, 2018; Kılınç, Karayel ve Koyuncu, 2018), çocukların büyük çoğunluğunun kendilerini yalnız hissetmedikleri, kendilerine güvendikleri, başarılı olacaklarını düşündükleri, ancak buna rağmen ülkelerine geri dönmek istedikleri belirtilmiştir (Gez, 2018). Ayrıca mülteci çocukların dil sorunlarının, ailelerinin kalabalık olmasının, sahip oldukları imkanların ve yaşadıkları çevresel koşulların iyi olma halleri üzerinde etkili olduğu saptanmıştır (Tatlıcıoğlu, 2019). Mülteci çocukların hane halklarının kalabalık olması, hane içerisinde büyük ve erkek çocuk olmak, babanın kaybı, hastalığı ya da ailede erkek çocuğun olmaması gibi etmenlerin varlığı çocukların erken yaşlarda çalışmaya sürüklenmelerine neden olmaktadır (Gül, Türkmen ve Nizam, 2019). Çocukların umut ve sosyal destek algıları arttıkça psikolojik sağlamlık düzeylerinin arttığını belirten çalışmalara da rastlanmaktadır (Bozdă̆, 2020). Yapılan çalışmalar incelendiğinde çocuklardan görüşme ya da ölçek uygulama yoluyla verilerin elde edildiği görülmektedir.

Alan yazında mülteci çocukların çizdikleri resimleri konu alan pek az çalışmaya rastlanmaktadır. Bu çalısmalarda mülteci çocukların çizimlerinde savaşa ilişkin unsurlara yer verdikleri (Filiz, Cancan ve Çelik, 2018; Pekşen Akça, 2016, Pekşen Akça ve Baran, 2016), çizdikleri resimlerde öncesinde yaşadıkları yerleri 
tasvir ettikleri, savaş öncesinde mutlu oldukları, geçmişe özlem duydukları (Aktın, 2018) görülürken, Türkiye'yi konu alan çalışmalarda çocukların iletişim sorunları olabileceği (Filiz, Cancan ve Çelik, 2018), Türkiye algılarında ise huzur, mutluluk ve özgürlük temalarının bulunduğu anlaşılmaktadır (Avc1, 2020). Özellikle küçük çocuklarla yapılan çalışmalarda resmin veri toplama aracı olarak kullanılması önemlidir. Eğer bu çocuklar mültecilerse dil sorunu yaşamaları, çekingen olmaları ve kendilerini ifade etmede güçlük çekmeleri gibi nedenlerden dolayı resim çizdirmek onlar hakkında daha kolay bilgi edinmeyi sağlayabilir. Resmin projektif bir yöntem olması nedeniyle çocuklar kendilerini daha rahat ifade eder. Çocuklar resim çizerken özgür şekilde renkleri kullanır, nesneleri istediği şekilde konumlandır ve çizgilere bazı anlamlar yüklerler (Pekşen Akça ve Baran, 2016). Bu gerekçeler 1şığında mülteci çocukların oyuna yönelik algılarını öğrenmek için resimlerinde kullandıkları unsurlar belirlenmiş, bu unsurlardan yola çıkarak bazı temalar oluşturularak mülteci çocukların oyuna ilişkin algılarının resim çizme yoluyla incelenmesi amaçlanmıştır.

\section{Yöntem}

$\mathrm{Bu}$ çalş̧mada mülteci çocukların oyuna ilişkin algılarının resim çizme yoluyla incelenmesi amaçlanmışır. Bu bölümde araştırmanın deseni, araştırmanın çalısma grubu, veri toplama araçları, veri toplama yöntemi ve verilerin analizi gibi başlıklara yer verilmiştir.

\section{Araştırmanın Deseni}

$\mathrm{Bu}$ çalışmada nitel araştırma yöntemlerinden biri olan durum çalışması (case study) deseni kullanılmıştır. Durum çalışmasında "güncel bir olgu, olay, durum, birey ve gruplar üzerine odaklanılıp, derinlemesine" incelenmeye çalışılmaktadır (Ekiz, 2003). Araştırmanın gerçekleştirilmesi için bazı özel durumların varlığına değinmek gerekmektedir. Bu tür çalısmalarda bir duruma ilişkin etmenler ortak bir paydada bütüncül bir şekilde araştırılır (Yıldırım ve Şimşek, 2013).

\section{Çalışma Grubu}

Araştırma 2019-2020 eğitim-öğretim yllında Hatay ilinin Reyhanlı ilçesinde yer alan bir devlet okulunda 01.10.2019-20.02.2020 tarihleri arasında gerçekleştirilmiş̧ir. Araştırmanın çalışma grubu nitel araştırma yaklaşımı kapsamında amaçlı örnekleme yöntemleri kullanılarak belirlenmiş; tipik durum örnekleme ile çalısma yapılacak okul; ölçüt örnekleme ile de çalşma grubu belirlenmiştir. Araştırmada çalışma grubu ölçüt örnekleme kullanılarak belirlenmiştir. Bu çalışma grubunun seçiminde önceden belirlenmiş bir dizi ölçüt kullanılmıştır (Yıldırım ve Şimşek, 2013). Bu bağlamda araştırmada "Mültteci cocuklar için Suriye'den gelmiss olma", "Hatay ilinin Reyhanh ilçesinde ikamet etme" ve "çalssmaya katulmaya gönüllï olma" ölçütleri dikkate alınarak çalışma grubu şekillendirilmiştir. Çalışma grubunun seçiminde Hatay ili Reyhanlı ilçesinde illkokul birinci sınıfa devam eden, çalışma grubunun seçimindeki ölçütleri taşıyan ve 01.10.2019-20.02.2020 tarihleri arasında eğitim-öğretime düzenli olarak devam eden çocuklar oluşturmaktadır. Temel ölçütler doğrultusunda gönüllülük esasına dayalı olarak çalışma gerçekleştirilmiş, etik ve gizlilik ilkelerine özen gösterilmiştir. Bu doğrultuda Hatay ili Reyhanlı ilçesindeki çocuklardan toplam $32(\mathrm{~K}=16, \mathrm{E}=16)$ çocuk cinsiyete göre eşit dağılım oluşturarak çalışma grubunu oluşturmaktadır. Çalışma grubunu oluşturan çocuklara ilişkin demografik bilgiler Tablo 1'de sunulmuştur.

Tablo 1. Araștırmaya Dâhil Edilen Çocuklara İlişkin Genel Özellikler

\begin{tabular}{|c|c|c|c|}
\hline Demografik $B$ & & $n$ & $\%$ \\
\hline \multirow{2}{*}{ Cinsiyet } & $\mathrm{K}_{12}$ & 16 & 50.0 \\
\hline & Erkek & 16 & 50.0 \\
\hline \multirow{2}{*}{ Doğum y1lı } & 2012 & 20 & 62.5 \\
\hline & 2013 & 12 & 37.5 \\
\hline \multirow{5}{*}{ Anne Öğrenim Düzeyi } & Okur-yazar değil & 28 & 87.5 \\
\hline & İlkokul mezunu & 3 & 9.3 \\
\hline & Ortaokul mezunu & 1 & 3.2 \\
\hline & Lise mezunu & - & - \\
\hline & Üniversite mezunu & - & - \\
\hline \multirow{5}{*}{ Baba Öğrenim Düzeyi } & Okur-yazar değil & 21 & 65.6 \\
\hline & İlkokul mezunu & 3 & 9.3 \\
\hline & Ortaokul mezunu & 5 & 15.5 \\
\hline & Lise mezunu & 1 & 3.2 \\
\hline & Üniversite mezunu & 2 & 6.4 \\
\hline \multirow{4}{*}{ Kardeş Sayısı } & Bir & - & - \\
\hline & İki & 3 & 9.3 \\
\hline & Ǘç & 5 & 15.5 \\
\hline & Dört ve üzeri & 9 & 75.2 \\
\hline \multirow{2}{*}{$\begin{array}{l}\text { Ailenin Yaşam Biçimi } \\
\text { (Türkiye'de) }\end{array}$} & Çekirdek & 4 & 2.5 \\
\hline & Akrabalarıla Birlikte & 28 & 97.5 \\
\hline
\end{tabular}


Tablo 1' de çocuk tanıma formu sayesinde edinilen veriler ışığında; çocuklardan 2012 y1lı doğumlu olanların sayısı (20), 2013 yılı doğumlu olanlardan (12) daha fazla olduğu söylenebilir. Dağılımda kız ve erkek çocukların sayılarının birbirleriyle aynı olduğu (16) annelerin çoğunluğunun okur-yazar olmadığı (28) bununla birlikte bir annenin lise mezunu olduğu, babaların öğrenim düzeylerine ilişkin dağılımlar incelendiğinde en yüksek frekans değerinin sırası ile okur-yazar değil (21), ortaokul (5) ve ilkokul (3) mezunu olduğu görülmektedir. Çocukların hiçbirinin ailede tek kardeş olmadığı, dört ve üzeri kardeşe sahip olanların sayısının en yüksek olduğu (9) çocukların çoğunluğunun akrabalarılyla birlikte (28) yaşadıkları götürmektedir.

\section{Veri Toplama Yöntemi}

Etik kurul izni (Erzincan Binali Yıldırım Üniversitesi İnsan Araştırmaları Etik Kurulu, Tarih: 30.04.2020, Protokol No: 04/06) ve çocukların ailelerinden onam alındıktan sonra araştırmaya başlanmıştır. Savaş nedeniyle göç etmek zorunda kalan çocukların oyuna ilişkin algılarını projektif bir yöntem olan resim çizme yoluyla incelenmesinin amaçlandığı çalışmada verilerin toplanması ve çocuklarla iletişim kurabilmek amacıyla uygulayıcı iki kez çocuklarla oyun etkinliği planlamış ve sınıf öğretmenlerinden çocuklarla olumlu iletişim geliştirmek için destek alınmıştır. Çocuklara ait genel bilgiler, çocukların kişisel dosyaları incelenerek toplanmıştır. Resim çalışmalarına geçilmeden önce çocuklarla tanışmak üzere sınıf ortamında çocuklarla bir araya gelinmiş, dosyalardan edinilen bilgiler doğrultusunda isimlerinin yazılı olduğu yaka kartları hazırlanarak; araştırmacının da dâhil olduğu boyama etkinliği yapılmış, etkinlik sonunda hazırlanan isim kartları takılarak çocuklarla kaynaşma sağlanmıştır. Araştırmacı hem çocuklarla tanışmak için hem de çocuklara ilişkin bilgilere ulaşmak için onlarla vakit geçirmiştir. Ertesi gün görüşmek üzere çocuklarla vedalaşmışıı. Uygulama yapılacak sınıf ortamı çocukların rahatça oturabileceği ve birbirlerinden etkilenmeyecekleri şekilde düzenlenmiş, çocuklara pastel boya malzemesi, beyaz renk A4 kâğıdı verilerek uygulamanın birinci basamağı olan "Severek oynadiğın bir oyunun resmini çizeer misin" yönergesi doğrultusunda resimlerin yapılması istenmiştir. Sınıf ortamına sekiz erli şekilde alınan çocuklara süre ile ilgili herhangi bir sınırlama konulmamıştır. Resim çalışmasını tamamlayan çocukların yaptıkları resimlerle ilgili anlattıkları hikâyeler araştırmacılar tarafindan "resmin hikâyesi" şeklinde bire bir kaydedilmiş ve çocuklara kod verilerek (K1, K2, E1, E2 vs.) yazıya dökülmüştür, yönergeler doğrultusunda 32 adet resim çalışmasına ulaşılmıştır.

\section{Verilerin Analizi}

Elde edilen veriler QSR N-VIVO 10 programı kullanılarak içerik analizine uygun şekilde çözümlenmiştir. İçerik analizi toplanan verilerin açıklanmasına yardımcı olacak kavramlar ve bu kavramlar arasındaki ilişkinin kurulmasını temel alır. Birbirlerine benzeyen veriler kavramlar ve temalar şeklinde bir çerçeve oluşturur. Sonrasında okuyucunun anlayacağı bir biçimde düzenlenerek yorumlanır. Bu amaçla veriler; verilerin kodlanması, temaların bulunması, kodların ve temaların düzenlenmesi ile bulguların tanımlanması ve yorumlanması aşamalarından geçirilerek analiz edilir (Yıldırım ve Şimşek, 2013). Bu kapsamda veriler kodlanarak sınıflamalar yapılmış ve temalar düzenlenmiştir. Bu işlemlerin ardından bulgular tanımlanarak yorumlanmıstır.

\section{Bulgular ve Tartışma}

Çocukların çizdikleri resimler onların psikolojik ve ruhsal durumları hakkında pek çok bilgi verir, bu durum resimlerin projektif bir özellik taşımasından kaynaklıdır. Örneğin yapılan çalışmalar büyük çizilen kulakların, başkalarının kendileri hakkında konuştuklarını düşünen kaygıll çocuklara ait olduğunu, kesik kesik çizilen resimlerin ve kâğıda iz bırakan kalın çizimlerin çocuk resimlerinde kaygıyı gösterdiğini (Yavuzer, 2016) ortaya koymaktadır. Çizimlerde silginin sıklıkla kullanılması ve çok fazla ayrıntıya yer verilmesi çocuğun kaygıları hakkında bize ipucu vermektedir (Çelik, 2016). Yine düşük boyutlu çizimlerin daha çok içe dönük, çekingen çocukların resimlerinde kendisini gösterirken (Akkapulu, 2010) psikoterapik olarak çocuğun iç dünyasını tanımamıza yardımcı olan bir araç olarak tanımlanır (Yavuzer, 2016). Başka bir ifade ile çocuğun çizimlerine yansıttığı detaylar onun bilinçaltında yer alan mutluluk, güven, sevinç gibi çeşitli duygularını, düşüncelerini somutlaştırarak düşüncelerini açık açık ortaya koymasını sağlar (Çelik, 2018). Bu doğrulta araştırma kapsamında çocukların çizdikleri resimler analiz edilmiş ve bulgular doğrultusunda tartışlıışır.

$\mathrm{Bu}$ çerçevede "Severek oynadığın bir oyunun resmini benim için çizer misin" yönergesi sonucunda çizdikleri resimlerde oyuna yönelik algılarına ilişkin çözümlemeler yapılmış, sonrasında bir kod 
listesi oluşturulmuştur. Oluşturulan kod listesi incelenerek yönerge sonucunda çocukların çizdikleri resimlere göre ayrı ayrı temalar belirlenmiştir. Bu temalar mülteci çocuklar için "Şiddet Unsurlarına Yer Verme", "Diğer İnsanlara Yer Verme", 'Doğa Unsurlarına Yer Verme" ve "Resmi Tamamlayıcı Unsurlara Yer Verme" şeklinde oluşmuştur. Bu yönergeye ait model aşağıda verilmiştir.

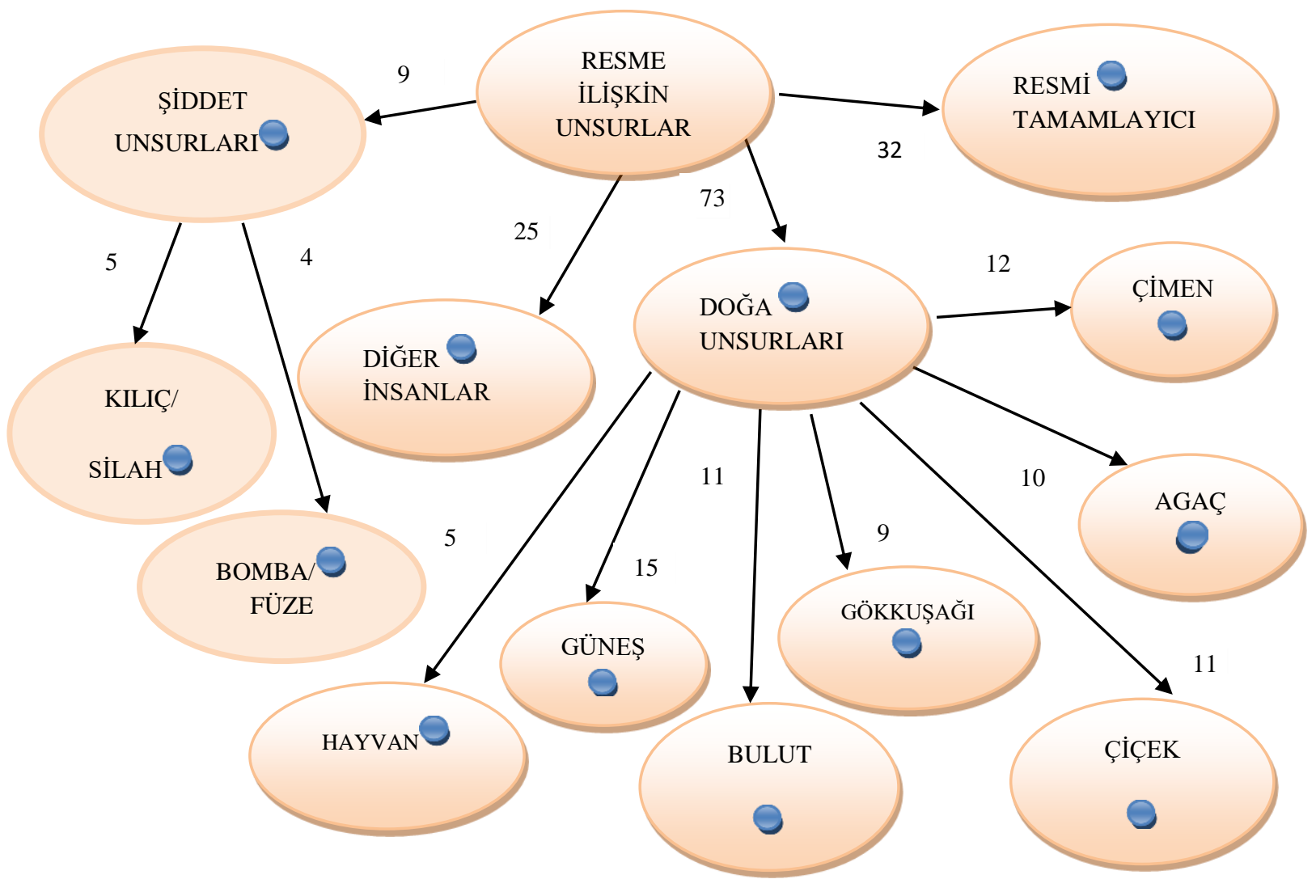

Model 1. Mülteci Cocuklarn Resimlerinde Yer Alan Unsurlara Ait Model

Tablo 2. Mülteci Cocuklara Ait Cizimimlerde Yer Alan Unsurlara İlişkin Sonuçlar

\begin{tabular}{llccc}
\hline & Resimde Yer Alan Unsurlar & Kiz (n) & Erkek (n) & Toplam (n) \\
\hline \multirow{2}{*}{ Şiddet Unsurlarına Yer Verme } & Kilıç/ Silah & 1 & 4 & 5 \\
& Bomba/Füze & 2 & 2 & 4 \\
\hline \multirow{2}{*}{ Diğer İnsanlara Yer Verme } & Evet & 10 & 15 & 25 \\
& Hayır & 6 & 1 & 7 \\
\hline \multirow{2}{*}{ Resmi Tamamlayıcı Unsurlar } & Evet & 17 & 15 & 32 \\
& Hayır & - & - & - \\
\hline \multirow{3}{*}{ Doğa Unsurları } & Güneş & 7 & 8 & 15 \\
& Hayvan & 1 & 4 & 5 \\
& Bulut & 6 & 5 & 11 \\
& Gökkuş̧ă̆1 & 1 & 8 & 9 \\
& Ağaç & 6 & 4 & 10 \\
\hline
\end{tabular}

Çocukların çizdikleri resimlerdeki unsurlara ilişkin oluşturulan model incelendiğinde; mülteci çocukların çizimlerinde diğer insanlara yer verdikleri (25), çizimlerinde en çok doğa unsurlarının yer aldığ1 (73), bunların en çok güneş (15), çimen (12), bulut ve çiçek (11) gibi unsurlardan oluştuğu ve çocukların çizimlerinde resmi tamamlayan unsurlara yer verdikleri (32) belirlenmiştir. Ayrıca çocukların çizimlerinde resmi tamamlayıcı unsur olarak kalp, yıldız, vazo vb. yer verdikleri, diğer insanlar olarak arkadaşlarını ve ebeveynlerini resimde konumlandırdıkları tespit edilmiştir. Bu durum bilişin ve duyguların temel evrenselliğini yansıtırken (Di Leo, 1983), çocukların yaşamında ve oyunlarında arkadaşlarının önemli bir yere sahip olduğunu, yaşanılan çevrenin aile fertlerinde duyulan hikâyelerin ve yaşanmışlıkların çocukların 
oyun tercihleri üzerinde belirleyici bir unsur olarak aktarıldığını göstermektedir. Mülteci çocukların insan figürlerine ilişkin çizdikleri resimler ve bu resimlere ilişkin tamamlayıc ifadeler aşağıda verilmiştir.

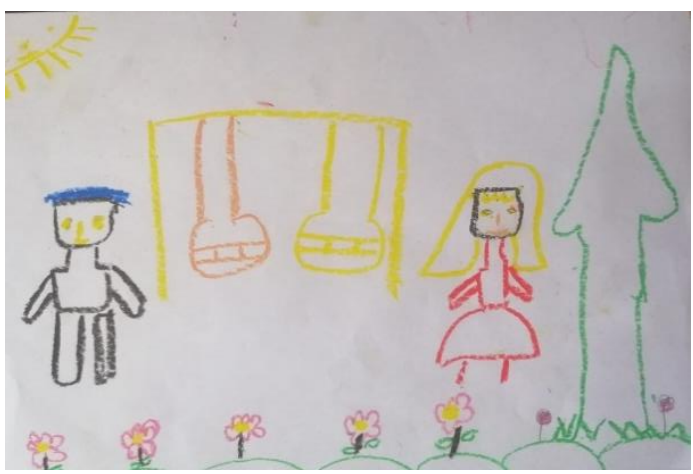

K11

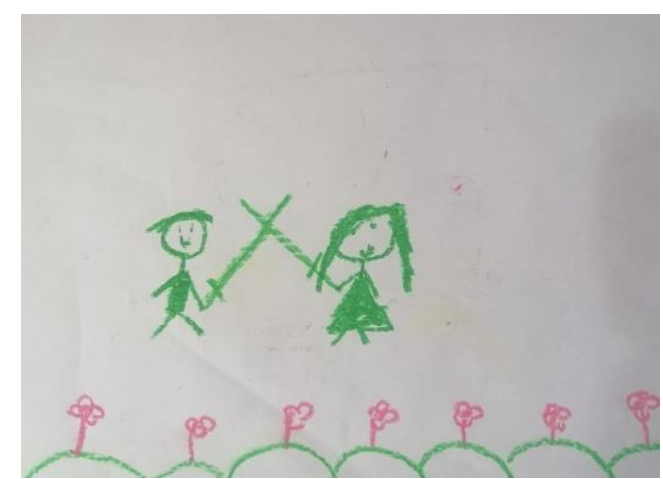

K7

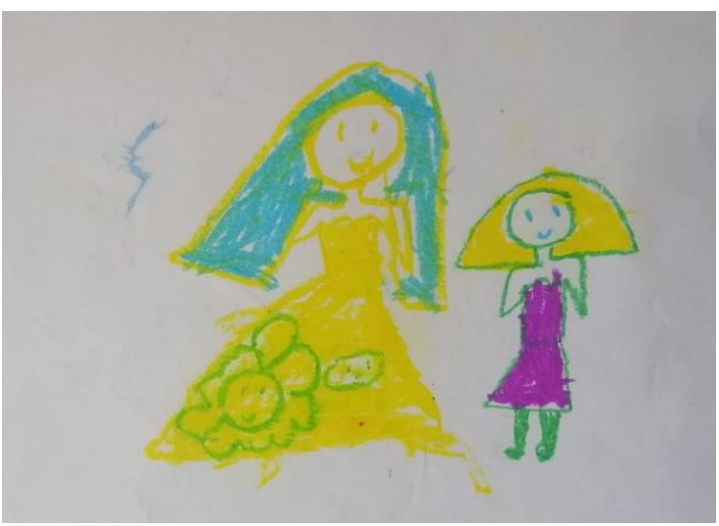

$\mathrm{K} 2$

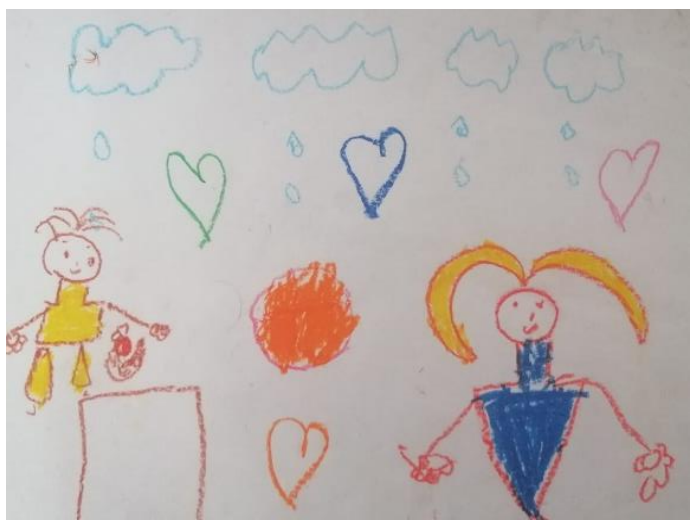

E9

Resim 1. Mülteci Cocuklarn İnsan Figürüne Ait Resim Örnekleri

Mülteci çocukların insan figürüne yer verdikleri çizimler incelendiğinde kâğgdın dikey şekilde konumlandırıldığı, figürün kalp, çiçek gibi tamamlayıcı unsurlar kullanılarak desteklendiği görülmektedir. $\mathrm{K} 11, \mathrm{~K} 7$ ve E9' un çizmiş olduğu resimlerde insan figürü olarak arkadaşlarına yer verdikleri, çizimlerin kâğıdın neredeyse tamamını kapladığı, yüzeyin rengini orijinal formda bırakmayı tercih ettikleri görülmektedir. K2'nin ise çiziminde oyun arkadaşı olarak annesine yer verdiği, çizimlerinde dekoratif ayrıntılar kullandığı görülmektedir. Nitekim çocukların iletişim kurdukları nesne ve figürlere çizimlerinde yer vermeleri beklenen bir gelişimsel özelliktir (Artut, 2004; Geçen, 2018). Resimlerde yer alan insan figürlerinin büyüklüğ̈nün özgüven, kişisel yeterlik alg1sı, benlik değeri ile ilişkili olduğu söylenebilir. Ebeveynleriyle ya da ailedeki diğer üyelerle etkileşim kurarken bazı sorunlar yaşayan çocukların ailelerini çizmek istemedikleri ya da bazı aile bireylerinin yer almadığı resimler ürettiklerini gösteren çalışmalar bulunmaktadır (Bombi, Pinto ve Cannoni, 2007; Cherney, Seiwert, Dickey ve Flichtbeil, 2006). Onlarnn çevreyle iletişiminin artması insan figürü çizmelerinde önemli bir etkendir (Geçen, 2018). Mülteci çocukların çizmiş olduğu resimlerde genel olarak renkleri kullanmaktan zevk aldıkları, mutlu ve neşeli detaylara yer verdikleri, çizimlerinde ayrıntıya girmedikleri görülmektedir. Çocukların çizgisel detaylarda akranlarıyla ilişskilerinin olduğu, onlarla oyun oynamaktan zevk aldıkları anlaşılmaktadır. Çizdikleri resimlerle ilgili resmin hikâyesinde de bu durumu doğrulayıcı ifadelere yer verdikleri görülmektedir. Ancak oynadıkları oyunların kimi zaman şiddet içerdiği görülmektedir (K7). Așağıda bu kodlamalara ilişskin referans cümlelerine yer verilmiştir; 
K11 "Oyun oynamay çok seviyorum. Kendimi baharda açan çiçek dallar gibi bissediyorum. Arkadaşımla salincakta sallanmak için parka gitmeyi de çok seviyorum"

K7: "Ben arkadaşımla kulıçcllk oynuyorum, ama şakacıktan çünkü ben iyi kalpli bir çocuğum”

K2: "Annemle her zaman güzel oyunlar, evcilikler, mutfakçılık, çiçeksilik oynarız annemle oyun oynamak çok. eğlenceli”

E9: "Kardeşimle oyun oynamayn çok seviyorum. Ö̆̆retmencilik, aşcllk, saklambaç her şeyi oynarm onunla, çok eğlenirim onunla, abimle de oynarken çok eğleniyorum"

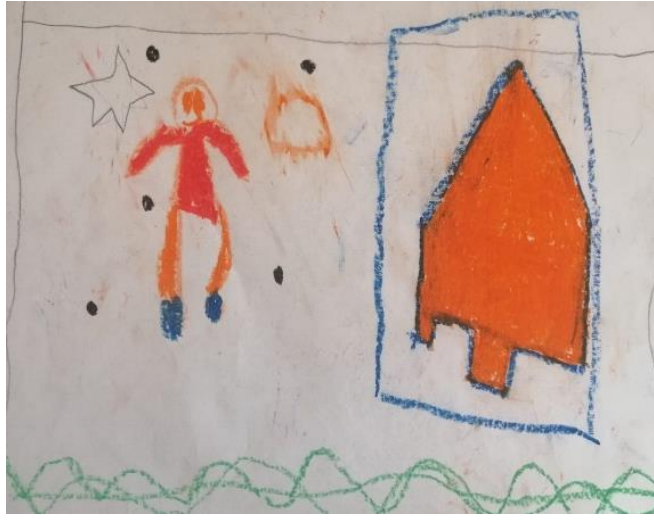

E8

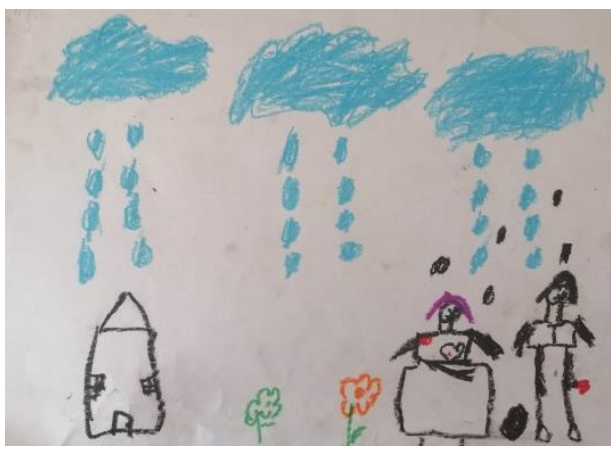

K16

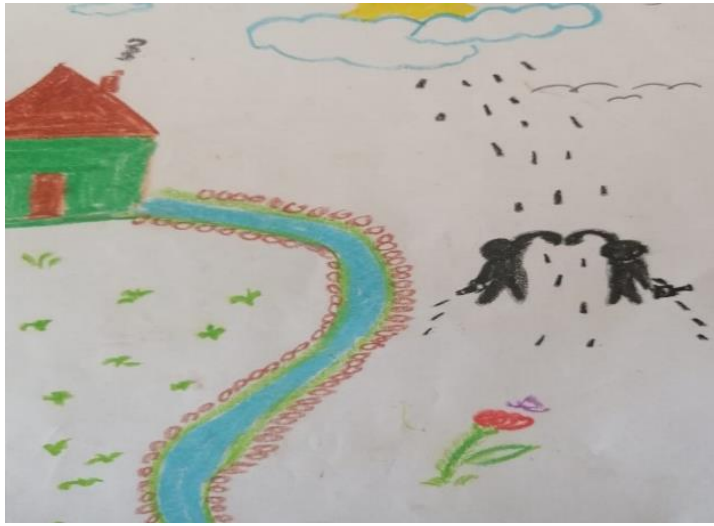

E6

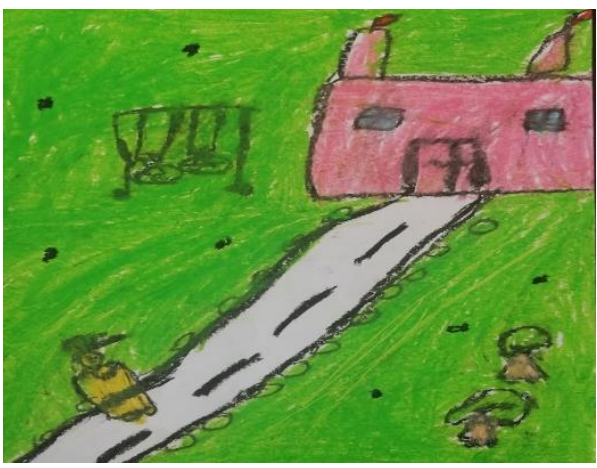

K13

\section{Resim 2. Mülteci Cocuklarn Ciæimlerinde Șiddet Unsurlarna Yer Verme Durumlarna Ait Resim Örnekleri}

Mülteci çocukların oyuna ilişkin algılarını konu alan çizimler incelendiğinde çocukların çizimlerinde şiddet unsurlarına yer verdikleri görülmektedir (9). Çocukların bu çizimlere ilişkin verdikleri açıklayıcı ifadeler aşağıdaki gibidir.

E8: "Cocuklar tek başına oyun oynarken dikekatli olmazlarsa başı belaya gider, mesela ates topu gelir evine de gidemer"

E6: "Cocuklar dişarida oynarken dikekatli olmąlarda gökyüzünden gelen siyah ve gri yağmurlar oyununu bozar, çok canlar acur"

K16: "Kardeşler bahçelerinde oynarlarken yağmurdan gelen siyah ateşler her tarafin kanatmış"

K13: "Evlerinin bahçesinde de oyun oynayan çocuklar varmış, sonra babası elindeki sopasyyla o toplara vurmaya çalısmıs, cocuklar parklarna yetisememis"

Çocukların çizimleri incelendiğinde, çizimlerde yer alan şiddet unsurlarının savaş koşullarını tasvir ettiği, bomba saldırılarının bulutların arasından çıkarak insanlara zarar verecek bir güce sahip olduğu ifade edilmiş, çocukların bu duruma ilişkin endişeleri sözel olarak belirtilmiş, ayrıca bu durum çizimlerine de yansımıştır. Benzer şekilde (Pekşen Akça (2016; Pekşen Akça ve Baran, 2016) yapılmış olan bazı 
çalışmalarda da savaş ortamını yaşamış veya savaşa ilişkin detayları çevresindeki diğer kişilerden duymuş olan çocukların çizimlerinde cinsiyet ayrımı gözetmeksizin savaşa ait izlere yer verdikleri, şiddet içeren unsurları kullandıkları belirlenmiştir. Nitekim çalışmamızla benzer olarak savaş sürecini yaşamış bireylerin, çocukların çevresinde yer alması, sürecin olumsuz etkilerinin bilerek ya da bilmeden çocuklara aktarmış olmaları çocukların çizimlerinde bu tür olumsuz ayrıntıların yer verilmesine neden olabilmektedir. Ayrıca mülteci çocukların çizimlerinde bu negatif ortamı yansıtan ayrıntılara yer vererek özellikle bu durumu tasvir ettikleri kısımlarda siyah rengi yoğun ve belirgin bir şekilde kullandıkları görülmektedir. Bach'a göre çocukların resimlerinde kullandığı renklerin belli anlamları vardır ve kullanılan rengin yoğunluğu önemlidir (Malchioldi, 2005). Nitekim renk ve duygularla ilgili yapılan araştırmalarda çok sağllklı sonuçlara ulaşılamamakla birlikte genel olarak siyah renk kullanılan resimlerin olumsuz ifadeler içerdiği (Büyükkarabacak, 2008) belirtilmektedir. Ayrıca gerçeği verme çabasından ötürü renklerde sıcak soğuk ayrımı yapmaksızın asıl renge sadık kalınmasının amaçlandığı bu yaş grubu çocuklarında sevdikleri renkleri ve coşkuları ifade edecek renkleri de kullanmaktan kaçınmadıkları da görülmektedir (Özsoy, 2005; Geçen, 2018). Çocukların çizimlerinde renkleri coşkuyla kullanmaları için bu konuda özgür olmaları ve süreye ilişkin bir sınırlanmanın da yapılmaması son derece önemlidir (Yavuzer, 2007).

Aşağıda farklı resimler için farklı yoğunlukta kullanılan renklerin yer aldığı örnekler verilmiştir.

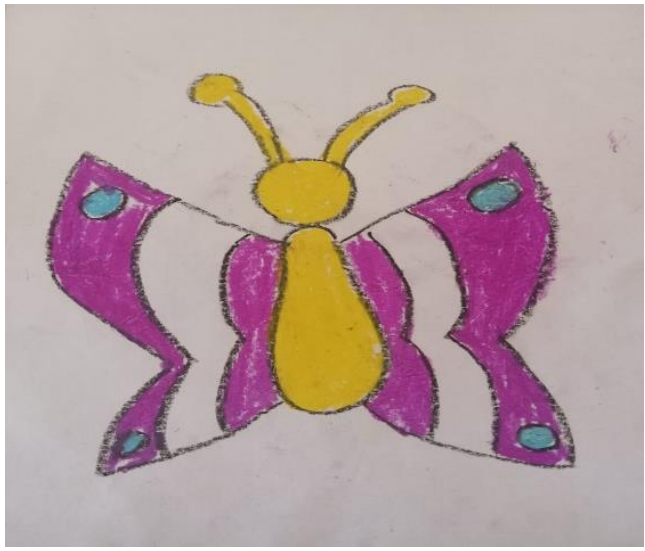

K6

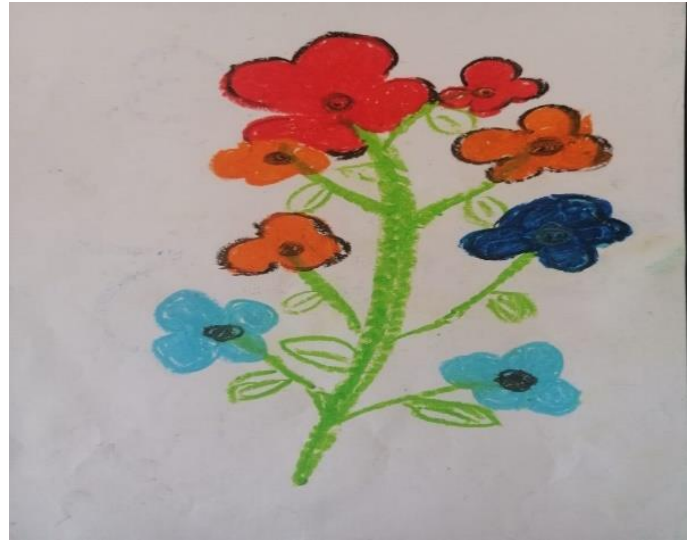

K1

Resim 3. Mülteci Çocuklarn Çižimlerinde Yer Alan Tamamlayuculara Ait Resim Örnekleri

Mülteci çocuklar tarafindan çizilen resimlerde K6 ve K1 benzetim olarak kelebek ve çiçek çizdikleri ifade edilirken, oyuna ilişkin bu benzetim yönleri şu şekilde anlatılmıştır: "Kelebek oyunu bir iyilik oyunudur, dünyanın her yerinde kötü durumdaki kişilere ulaşacak kanatların vardır. Bu oyun sevgi oyunu, iyilik perisi oyunudur" şeklinde ifade edilmiştir (K6). "Çiçekler mutluluk verir, oyunlardaki mutluluk gibi dallardaki açan çiçeklerin sayısı arkadaşlarım gibi çoktur, sevgimiz gibi sıcaktır" şeklinde ifade edilmiştir (K1). Bununla birlikte çocukların tamamının resimlerine ilişkin anlattıkları hikâyelerde olumlu duygulara (mutluluk, barış, huzur, iyilik, sevmek vb.) yer verdikleri saptanmıştır. Çocuklar, çizdikleri resimler aracıllı̆ı ile duygularını yansıtmakta, sözel olarak ifade edemedikleri birçok duygu ve düşünceyi resimler yolu ile dile getirebilmektedir (Whaley ve Wong, 1999; Tielsch ve Jackson-Allen, 2005). Ayrıca çocukların resimlerinde genel olarak kâğıdı yatay olarak konumlandırdıkları (31) ve zemin kavramına yer verdikleri (22), oyunu konu alan resimlerinde yer alan figürleri dışarıda çizmeyi tercih ettikleri (28) görülmektedir.

\section{Sonuç ve Öneriler}

Savaş nedeniyle göç etmek zorunda kalan mülteci çocukların oyuna ilişkin algılarını projektif bir yöntem olan resim çizme yoluyla incelenmesinin amaçlandığı bu çalışmada;

- Çocukların resimlerinde savaşa ilişkin unsurların yer aldığı, ancak gerek çizimlerinde gerekse anlattıkları hikâyelerde mutlu olmayı tercih ettikleri, bu olumlu durumu da resimlerine yansıttıkları ve sözel olarak ifade ettikleri görülmektedir.

- Mülteci çocukların çizgisel aşamalara uygun olarak resimlerinde insan figürü, doğa figürleri ve ev figürlerini kullandıkları gibi resimlerinde tamamlayıcı ayrıntılara yer verdikleri genel olarak bu 
unsurları resim kâğıdına yatay olarak konumlandırdıkları, yüzeyi boyamaktan kaçındıkları görülmektedir.

- Mülteci çocukların resimlerinde çoğunluklu olarak kendilerine yer verdikleri, genel olarak kendilerini açık alanla konumlandırdıkları, bununla birlikte oyun arkadaşı olarak arkadaşları ve anne, abla, abi gibi aile fertlerini de resmettikleri görülmüştür.

- Mülteci çocukların resimlerinde renkleri coşkuyla kullandıkları, savaşa ilişkin unsurların yer aldığı resim çalş̧malarında özellikle siyah rengin belirgin ve vurgulayıcı bir şekilde kullanıldığı görülmektedir.

Göç sonrası ülkesini terk etmek zorunda kalan çocukların yeni bir bölgeye uyum sağlama, stres, aile çatışmalarının neden olduğu depresyon gibi psiko-sosyal sorunlarla karşı karşıya kaldıkları bilinmektedir. Benzer şekilde göçle birlikte yeni çevreye uyum (Angay, 2010), yalnızlık, sosyal izolasyon, yabancılık (Tuzcu ve Bademli, 2014), sosyal destek ağlarını kaybetme (Gülşen, Knipscheer ve Kleber, 2010), dil ve iletişim sorunları, dışlanma, önyargı (Angay, 2010; Nar, 2008), bölgesel ve kentsel ayrımcilığa maruz kalma (Nar, 2008) gibi pek sorunlar yaşanmakta, bu sorunların yol açtığ1 etkilerle çocuklar baş etmeye çalısmaktadır. Göçü yaşamış, yeni bir bölgeye uyum sağlamak zorunda olan çocukların bu durumla başa çıkabilmesi adına sosyal destek ağlarının yaygınlaştırılması ve sosyal iletişimin güçlendirilmesi son derece önemlidir (Bozdağ, 2015). Özellikle savaş nedeniyle ülkesini terk etmek zorunda kalan çocuklar için bu yönlü ortamların var olması çocukların olumsuz duygularla da baş etmesini sağlayarak hayata ilişkin motivasyonlarını artıracaktır.

Bu sonuçlar doğrultusunda şu öneriler verilebilir;

Çocuğun gelişimi ve eğitimi açısından sağlıklı bir ortamda büyümesi son derece önemlidir. Bu doğrultuda çocuklar için destekleyici hizmetlerin hazırlanması ve uygulanması gereklidir. Çocuğun hem gelişimine destek olmak hem de savaş ortamının getirdiği travmatik durumun yol açtığı olumsuzlukları gidermek için oyun ve oyun materyallerine ulaşılabilirlik son derece önemlidir. Çünkü oyun çocuğun işidir ve yaşamın kendisidir (Gökşen, 2014). Mülteci çocuklar başta olmak üzere pek çok çocuk için oyun materyallerine ulaşlabilirlik, oyun ortamındaki yetersizlikler çocukluğun temel problemidir. Çocuklar oyun etkinlikleri yapabilecekleri, farklı aktiviteler gerçekleştirebilecekleri ortamlara ihtiyaç duymaktadır. Çocukların özgürce resim yapabilecekleri, sanatın farklı alanlarına yönelebilecekleri, malzemelere ulaşmakta sıkıntı yaşamayacakları, kendilerini rahatça ifade edebilecekleri ortamlar devlet ve özel kurum desteği sağlanarak oluşturulabilir. Bu ortamların var olması çocukların yaratıcı yönlerini geliştirerek, çok yönlü düşünme becerileri geliştirmelerine katkı sağlayarak gelişimlerini olumlu yönde etkileyecektir.

\section{Etik Beyan}

"Mülteci Cocuklarn Resimlerinde Oyun Algıssı" başlıklı çalışmanın yazım sürecinde bilimsel kurallara, etik ve alıntı kurallarına uyulmuş; toplanan veriler üzerinde herhangi bir tahrifat yapılmamış ve bu çalşsma herhangi başka bir akademik yayın ortamına değerlendirme için gönderilmemiştir. Etik kurul izni Erzincan Binali Yıldırım Üniversitesi İnsan Araştırmaları Etik Kurulu’ndan (Tarih: 30.04.2020, Protokol No: 04/06) alınmıştır.

\section{Kaynakça}

Akkapulu, F. (2010). İnsan çizimlerinin projektif bir yöntemle değerlendirilmesi. Yansitma Psikopatoloji ve Projektif Testler Dergisi, 14, 15-20.

Aktın, K. (2018). Sığınmacı çocukların mutluluk temalı resimlerinden yansımalar. Elementary Education Online, 17(3), 1524-1547.

Angay, H. (2010). Doğu ve Güneydoğu illerinden İzmir'e gọ̈c eden ailelerin çocuklarnmn okul sorunlarmnn incelenmesi (Yüksek Lisans Tezi). Ege Üniversitesi, İzmir.

Artut, K. (2005). Sanat eğitimi ve yöntemleri. Ankara: Anı Yayıncillk.

Attanayake, V., Mckay, R., Joffres, M., Singh, S., Burkle Jr, F. ve Mills, E. (2009). Prevalence of mental disorders among children exposed to war: a systematic review of 7,920 children. Medicine Conflict And Survival, 25(1), 4-19.

Avcı, A. (2020). 9-14 yas çocuklarn resimsel anlatumlarnda göcs ve göcmenlik algısı (Yüksek Lisans Tezi). Pamukkale Üniversitesi Eğitim Bilimleri Enstitüsü, Denizli.

Aydoğdu, F. (2019). Gösmen aile çocuklarmn uyum düreylerine sosyal uyum eğitim programmn etkisinin incelenmesi (Doktora Tezi). Ankara Üniversitesi Sağlık Bilimleri Enstitüsü, Ankara.

Bahadır, H. ve Uçku, R. (2016). İzmir'in Bir Mahallesinde Yaşayan 6-17 Yaş Arasındaki Suriyeli Çocukların Çalışma Durumları ve Çalışma Durumların Etkileyen Etmenler. Dokuz Eylül Üniversitesi Tap Fakïltesi Dergisi, 30(3), 117124. Erişim adresi: http://static.dergipark.org.tr/article-download/0911/41d3/ee41/5a3cb8bab198f.pdf? 
Baş, M., Molu, B., Tuna, H. ve Baş, İ. (2017). göç eden ailelerin sosyo-kültürel ve ekonomik değişiminin kadın ve çocuk yaşamına etkisi. Itobiad: Journal of The Human Social Science Researches, 6(3), 1680-1693. Erişim adresi: http://static.dergipark.org.tr/article-download/4e10/b33a/8a10/5998820acd92b.pdf?

Bombi, A. S., Pinto, G. ve Cannoni, E. (2007). Pictorial assessment of interpersonal relationships (pair). An analytic system for understanding children's drawings. Firenze: Firenze University Press.

Bozdağ, F. (2015). İ̧ gösc yaşamış ve yaşamamış ergenlerin benlik kurgular, uyum sorunlar ve başa çıkma tarß̨lar (Yüksek Lisans Tezi). Hacettepe Üniversitesi Eğitim Bilimleri Fakültesi, Ankara.

Bozdağ, F. (2020). Mülteci çocuklarn psikolojik sağlamlılar ve kültürlenme stratejilleri (Doktora Tezi). Hacettepe Üniversitesi Eğitim Bilimleri Fakültesi, Ankara.

Cherney, I. D., Seiwert, C., Dickey, T. M., \& Flichtbeil, J. D. (2006). Children's drawings: A mirror to their minds. Educational Psychology, 26 (1), 127-142. doi: 10.1080/01443410500344167

Çelik, F.Y(2018). 9-12 yaş grubu çocukların çizdikleri resimlerle depresyon, kayg1 ve özsayg1 değişkenleri arasındaki ilişskilerin incelenmesi (Yüksek Lisans Tezi). Işık Üniversitesi Sosyal Bilimler Enstitüsü, İstanbul.

Derluyn, I., \& Vervliet, M. (2012). The well-being of unaccompanied refugee minors. In health inequalities and risk factors among migrants and ethnic minorities. Cost series on health and diversity. Edited By David Ingleby, Allan Krasnik, Vincent Lorant And Oliver Razum. Antwerp-Apeldoorn: Garant Publishers, 1, 95-109.

Di Leo, J. H. (1983). Interpreting children's drawing. New York: Brunner/Mazel.

Düzel, B. ve Alış, S. (2018). Türkiye'de uluslararası düzensiz göç gerçeğinde refakatsiz göçmen çocukların durumu ve başlıca risklerin değerlendirilmesi. Asia Minor Studies, 6, 258-274.

Ekiz, D. (2003). Eğitimde araștırma yöntem ve metodlarna giriş: Nitel, nicel ve eleştirel kuram metodolojileri. Ankara: Anı Yayinc1lik.

Fazel, M. ve Stein, A. (2002). The mental health of refugee children. Archives of Disease in Childhood, 87(5), 366-370.

Filiz, S. B., Cancan, D. A. ve Çelik, F. K. (2018). Suriyeli çocukların Suriye'ye bakış açılarına ilişkin resimlerinin analizi. Abi Evran Üniversitesi Kirşehir Ë̆gitim Fakültesi Dergisi, 9(1), 519-536.

Geçen, F. (2018). Çocuğun gelişimsel basamaklarına göre figürleri ele alma biçimleri. Avrasya Sosyal ve Ekonomi Araștirmalar Dergisi, 5(10), 60-83. Erişim adresi: http://static.dergipark.org.tr/articledownload/991d/7d4a/dbb9/5c151a95912bb.pdf?

Gez, A. (2018). Suriyeli çocuk ve ergenlerde algılanan sosyal destek ve psikolojik sağlamlık arasındaki ilişki (Yüksek Lisans Tezi). Çağ Üniversitesi Sosyal Bilimler Enstitüsü, Mersin.

Gül, S. S., Türkmen, E. ve Nizam, Ö. K. (2019). Türkiye'de emeğin en savunmasız hali: Şanlıurfa'da Suriyeli mülteci çocuk işçi olmak. Calıs̆ma ve Toplum, 61(2), 917-940. Erişim adresi: file:///C:/Users/bidb/Downloads/Turkiyede_Emegin_En_Savunmasiz_Hali_Sanl.pdf

Gülşen, C., Knipscheer, J. ve Kleber, R. (2010). The impact of forced migration on mental health: a comparative study on posttraumatic stress among internally displaced and externally migrated Kurdish women. Traumatology, 16(4), 109-116.

Gökşen, C. (2014). Oyunların Çocukların Gelişimine Katkıları ve Gaziantep Çocuk Oyunları A. Ü. Türkiyat Arasstrmalar Enstitüsü Dergisi [TAED] 52: 229-259.

Hanson, G. ve Woodruff, C. (2003). Emigration and educational attainment in Mexico. Mime: University of California At San Diego.

Hing, V., Lun, P. ve Phann, D. (2014). The impacts of adult migration on children's wellbeing. The Case of Cambodia. Cambodia Development Resource Institute (Cdr1), Final Report, 1-36.

Kardeş, S. (2018). Mülteci cocuklarn psikososyal gelişimine yönelik program uyarlanması (Doktora Tezi). Hacettepe Üniversitesi Eğitim Bilimleri Fakültesi, Ankara.

Kellert, S. (1996). The value of life, biological diversity and human society. Washington: Island Press.

Kılınç, F. E., Karayel, F. ve Koyuncu, M. (2018). Türk ve Suriyeli çocukların göç kavramına ilişkin metaforlarının belirlenmesi. Sosyal Politika Calısmalar Dergisi, 18(40/2), 37-54.

Lawrence, J. A., Dodds, A. E., Kaplan, I. ve Tucci, M. M. (2019). The Rights of Refugee Children and The un Convention on The Rights of The Child. Laws, 8(3), 20, 1-22.

Malchiodi, C. A. (1998): Cocuklarn resimlerini anlamak. İstanbul: Epsilon Through, Toronto: Inner City Boks, 2 Edition.

Nar, B. (2008). Göģün eğitime ve eğitim yönetimine etkileri: Dilovası Örneği (Yüksek Lisans Tezi). Sakarya Üniversitesi, Sakarya.

Özdemir, A. ve Budak, F. (2017). Göçün çocuk ruh sağlığ1 üzerine etkileri. Kadem Kadın Araşttrmalar Dergisi, 3(2), 212-223. Erişim adresi: http://kadinarastirmalari.kadem.org.tr/wp-content/uploads/ 2018/02/ 212_223.pdf

Özsoy, V. (2005). İlköğretimde sanat eğitimi ve kuralları. İstanbul: Görsel Sanatlar Eğitimi Derneği Yayınları.

Pekşen Akça, R. (2016). Resimler yoluyla mülteci çocukların şiddet alg1sı nitel bir araştırma. Elmis International Congress of Special Education, 12-15 May1s, Konya.

Pekşen Akça, R. ve Baran, G. (2016). Investigation of game perception of Syrian refugee children attending to first grade of primary school by using picture drawing method. International Journal of Humanities and Social Science Inventıon, 5, 16-23. Erişim adresi: http://www.ijhssi.org/papers/v5(12)/C05121623.pdf

Pottinger, A. ve Brown, S. (2006). Understanding the impact of parental migration on children: Implications for counseling families from the caribbean. Vistas 2006 Online. 
Rossi A (2008). The impact of migration on children in developing countries. Paper presented at the Youth Migration Conference, 24-26 April, Bellagio, Italy.

Saleh, A., Aydın, S. ve Koçak, O. (2018). A comparative study of syrian refugees in Turkey, Lebanon and Jordan: Healthcare access and delivery. Opus Uluslararası Toplum Arasttrmalan Dergisi, 8(14), 448-464.

Sirin, S. ve Rogers-Sirin, L. (2015). The educational and mental health needs of Syrian refugee children (P. 13). Washington, Dc: Migration Policy Institute.

Tatlıcioğlu, O. (2019). Suriyeli çocuklarn iyi olma ballerinin incelenmesi: Altındağ örneği (Doktora Tezi). Hacettepe Üniversitesi Sosyal Bilimler Enstitüsü, Ankara.

Tielsch, A. H. ve Jackson-Allen, P. (2005). Listen to them draw: Screening children in primary care throught to use of human figure drawings. Pediatric Nursing, 31(4), 320-327. Erişim adresi: http://eds.b.ebscohost.com/eds/pdfviewer/pdfviewer?vid=0\&sid=e5d9e743-30e4-4bec-a579d06f0163d3c1\%40pdc-v-sessmgr06

Vanore, M. (2015). Family-member migration and the psychosocial health outcomes of children in Moldova and Georgia. Maastricht University.

Wang, F., Zhou, X. ve Hesketh, T. (2017). Psychological adjustment and behaviours in children of migrant workers in China. Child: Care, Health And Development, 43(6), 884-890.

Whaley, L. F. ve Wong, D. L. (1999). Nursing care of infants and children. St. Louis: Mosby Year Book

Yavuzer, H. (2007). Resimleriyle cocuk. İstanbul: Remzi Kitabevi.

Yavuzer, H. (2016). Resimleriyle çocuk. İstanbul: Remzi Kitabevi.

Yıldırım, A. ve Şimşek, H. (2013). Sosyal bilimlerde nitel araştırma yöntemleri. Seçkin Yayıncılık: Ankara.

\section{EXTENDED ABSTRACT}

Few studies on the pictures drawn by refugee children are encountered in the literature. In these studies, it is seen that refugee children include elements of war in their drawings, depict the places they lived in before their paintings, they were happy before the war, and they yearn for the past; children's communication problems study in our country, the perception of Turkey, it is observed that the theme of peaces, happiness and freedom. It is important to use the picture as a data collection tool especially in studies with young children. If these children are refugees, drawing pictures for reasons such as having language problems, being shy and having difficulty expressing themselves may provide easier information about them. As the picture is a projective method, children express themselves more comfortably. Children freely use colors when they draw pictures, position objects as they wish and give some meaning to the lines. In the light of these reasons, the elements used in their paintings to determine the perceptions of refugee children about the game were determined, and based on these elements, some themes were created and the perceptions of refugee children about the game were examined through drawing. In this study, it is aimed to examine the perceptions of refugee children about the game through painting. Case study pattern, which is one of the qualitative research methods, was used in the research. In the research, the working group was determined according to criterion sampling.

In this context, the study group was formed by taking into consideration the criteria of "coming from Syria due to war", "Inhabiting in the district of Reyhanlı in the province of Hatay" and "volunteering to participate in the study". For this purpose, $32(\mathrm{E}=16 ; \mathrm{K}=16)$ refugee children who attended the first year of primary school in the city center of Hatay in the 2019-2020 academic year and migrated to Hatay in the last year due to war were included in the research. In order to collect data and communicate with children, the practitioner planned a game activity with children twice and support was received from classroom teachers to develop positive communication with children. General information about children was collected by examining the personal files of the children. Before starting painting works, children were met in the classroom to meet with the children, and the name cards with their names were written in line with the information obtained from the files; The painting activity including the researcher was held, and the name cards prepared at the end of the activity were inserted and socialization was provided with the children. The researcher spent time with them both to meet the children and to access information about them. He said goodbye to the children to meet the next day. The classroom environment where the implementation will be made was arranged in such a way that children can sit comfortably and not be affected by each other, and the children were asked to make pictures in line with the directive, "Would you draw a picture of a game you play for me", which is the first step of the application by giving children pastel paint material, white color A4 paper. Children who have been taken to the classroom environment in eight ways have no restrictions on the duration. The stories told by the researchers about the pictures made by the children who completed the painting work were recorded by the researchers as "the story of the picture" and they were written by giving the code (K1, K2, E1 and K1, K2 etc.) and 32 painting studies were reached in accordance with the instructions. The data obtained were analyzed in accordance 
with the content analysis using the QSR N-VIVO 10 program. In this context, classifications were made by encoding the data and themes were organized. After these processes, the findings were identified and interpreted. When the data were analyzed, it was observed that themes such as "G Violence Elements", "Placing Other People", "Placing Nature Elements" and "Placing Official Complementary Elements" were formed. Children's violence such as swords / weapons and bombs / missiles; It was observed that they included nature elements such as sun, animal, cloud, rainbow, tree, grass and flower. Similarly, it was determined that children included houses, trees, grass, flowers and sun as complementary elements of the picture. When the drawings in which the children included the human figure were examined, it was determined that the paper was positioned vertically and the figure was supported by using complementary elements such as heart and flower. As a result, it is seen that there are elements related to war in children's paintings, but children prefer to be happy both in their drawings and the stories they tell, they reflect this positive situation in their paintings and express them verbally. It is seen that refugee children use human figures, nature figures and house figures in their paintings in accordance with their linear stages, as well as complementary details in their paintings, generally using these elements horizontally on painting paper and avoiding painting. In the paintings of the refugee children, it was observed that they mostly included them, positioned themselves with the open space in general, but also depicted friends and family members such as mothers, sisters and brothers as playmates. It is seen that especially in the paintings of refugee children, colors are used in colors and war elements are used especially in black. It can be created by providing state and private institutional support for environments where children can freely paint, turn to different areas of art, have no trouble accessing materials, and express themselves comfortably. The existence of these environments will positively affect their development by improving their creative aspects and contributing to the development of multi-faceted thinking skills. Especially for children who have to leave their country due to the war, the existence of these directional environments will increase their motivation for life by ensuring that children also deal with negative emotions. 